\title{
SEISMIC ANALYSIS OF MULTI-STORIED RCC BUILDING WITH CRESCENT SHAPED BRACING IN GROUND SOFT STOREY
}

\author{
Pallavi Partani \\ P.G. Student Department of Civil Engineering \\ Saraswati College of Engineering, Kharghar, \\ Maharashtra, India
}

\begin{abstract}
A common cause for collapse of multi-storeyed RCC building due to earthquake is occurrence of soft storey in ground floor due to presence of infill wall in upper story leading to stiffness irregularity between floors and increased shear force in ground floor columns. In current design practices stiffness and energy absorption system are combined in single system. Various soft storey strengthening techniques like use of steel bracings, dampers, column jacketing etc. have been studied in past. This paper focuses on studying the effect of special type of bracing as Crescent shaped steel bracing in ground soft storey of a $\mathbf{G + 1 2}$ storied RCC building located in Zone III, India. Response spectrum analysis is carried out for the structure using ETABS2015 software and results are computed based on storey displacement, drift, stiffness, time period and base shear.
\end{abstract}

Keywords - Soft storey, Crescent shaped steel bracing, Response spectrum analysis

\section{INTRODUCTION}

Earthquakes are the most disastrous and and unexpected natural calamities in the world". It has occurred in India,, China, Nepal, Japan, Indonesia and many other parts of the world killing hundreds of thousands of people. Earthquakes do not kill the people but unsafe buildings do. The various factors which contribute to the unsafe buildings are vertical and plan irregularities, strength and stiffness irregularity, mass irregularity, torsion irregularity etc.

Due to urbanization and increase in population most of the reinforced building has a special feature i.e. ground is left open for the purpose of social and functional needs like vehicle parking, shops, reception lobbies, a large space for meeting room .Such buildings are often called open ground storey buildings or soft story buildings. These buildings have no infill wall in ground storey but upper storeys are with infill wall. In these arrangements upper floors are more rigid than their base. In such building dynamic ductility demand during

\author{
Roshni John \\ Associate Professor, Department of Civil Engineerng \\ Saraswati College of Engineering, Kharghar, \\ Maharashtra, India
}

probable earthquake gets more concentrated in soft storey and upper storey mean to remain elastic.

According to IS 1893 (Part 1): 2016 clause 4.20 soft storey is one in which the lateral stiffness is less than Strengthening of soft storey building is needed to improve its seismic performance. This can achieved either by local strengthening method or by global strengthening techniques.

In this report we are focusing on strengthening soft storey by use of bracing system to avoid ground soft storey collapse. A new innovative device known as Crescent shaped bracing will be used to strengthen the ground soft storey.

\section{Braced frame structure}

Incorporation of bracing is another common effective approach which can be designed to provide stiffness, strength, ductility and energy dissipation. This technique can effectively reduce the risk of soft storey frame by providing adequate stiffness to the frame. Crescent-Shaped brace (CSB) is a special lateral resisting device that is capable of providing additional design freedom to frame structures. its peculiar shape, allows design its lateral stiffness independently from its initial yield strength thus appearing suitable to be used for an enhanced lateral resisting system.

In general, for steel bracing $=\mathrm{K}=\frac{\mathrm{AE}}{\mathrm{L}} \cos ^{2} \theta$ For crescent shaped steel bracing $=$

$\mathrm{K}=\frac{\mathrm{a} T \mathrm{E}}{\mathrm{G}^{2} \mathrm{~L}} \cos ^{2} \theta$, (for Single CSB), which implies

where, $\mathrm{K}$ - Stiffness of the element

A - Cross-section area of the element

$\mathrm{L}$ - Length of the element

$\theta$ - Angle w.r.t. horizontal

$\mathbf{J}$-moment of inertia of the element $\mathrm{d}$ - Peak height of the element 


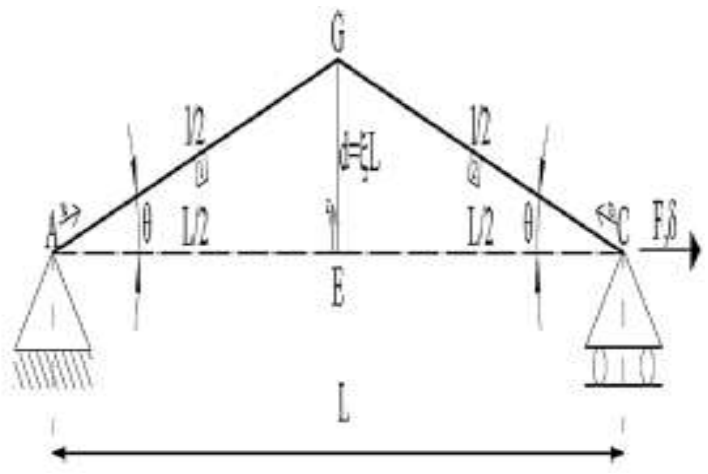

Fig 1- geometric representation of single CSB

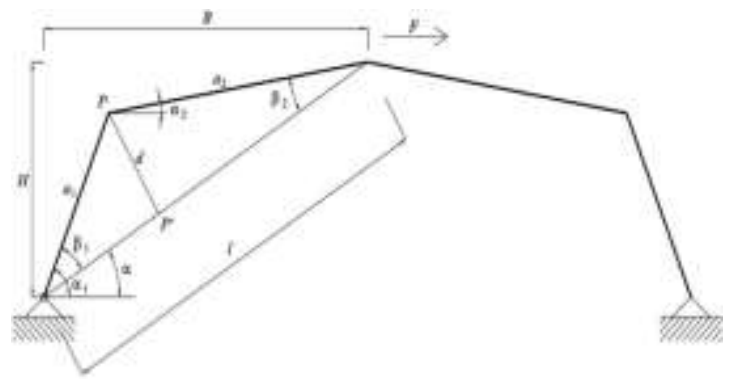

Fig 2 - geometric representation of Coupled CSB

II. VARIOUS MODELS USED FOR ANALYSIS

Total three models are studied in this paper Model 1-Bare frame

Model 2-Bare frame equipped with first type of CSB Model 3- Bare frame equipped with first type of CSB

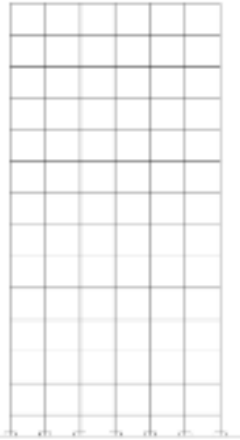

Fig 3 - model 1

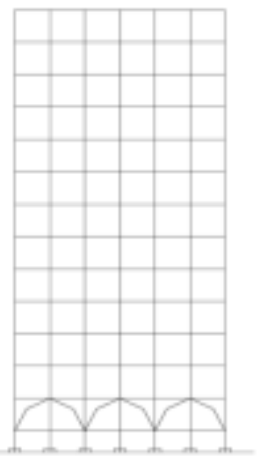

Fig 4 - model 2

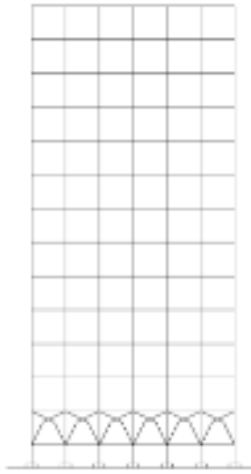

Fig 5 - model 3

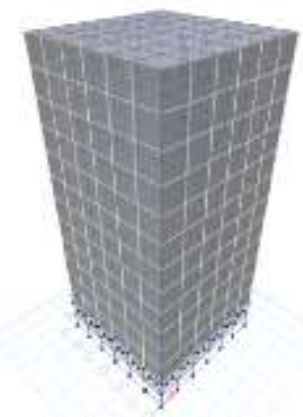

Fig 6-3-D view

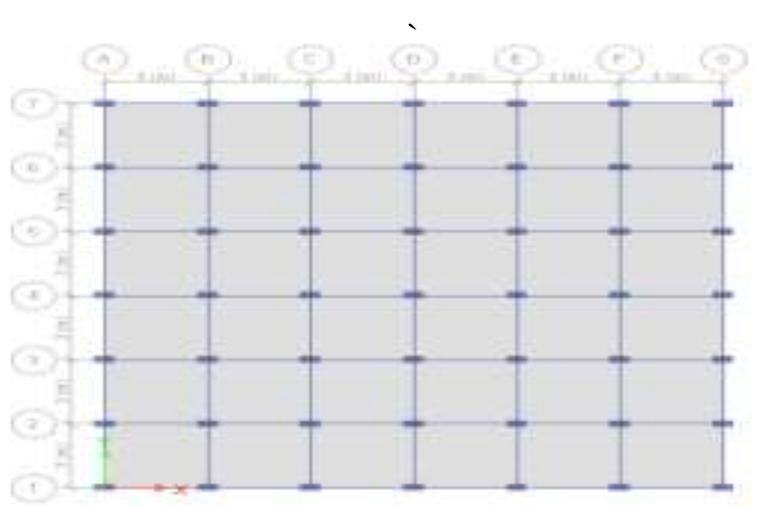

Fig 7 -Plan view of building

\section{Description of analytical model}

The building considered for design is a $\mathrm{G}+12$ storied RCC framed structure building located in Zone III, India.IS 456:200 and IS 1893:2016 are used for design.

Height of building $-39 \mathrm{~m}$

Plan dimension - $18 \mathrm{~m}$ X18m

Grade of concrete and steel
a) Beam and slab- M20
b) Column - M25
c) rebar-Fe 415
d) Steel- Fe 345

Size of various element of structure

1) beam-300 $\times 500$

2) column- $300 \times 600$ 
International Journal of Engineering Applied Sciences and Technology, 2019

Vol. 4, Issue 3, ISSN No. 2455-2143, Pages 226-229

Published Online July 2019 in IJEAST (http://www.ijeast.com)

3) Slab thickness- $150 \mathrm{~mm}$

4) Steel bracing - ISMC 250

\section{RESULTS AND DISCUSSIONS}

Response spectrum analysis was carried out to find the response of all models and result obtained are as follows :

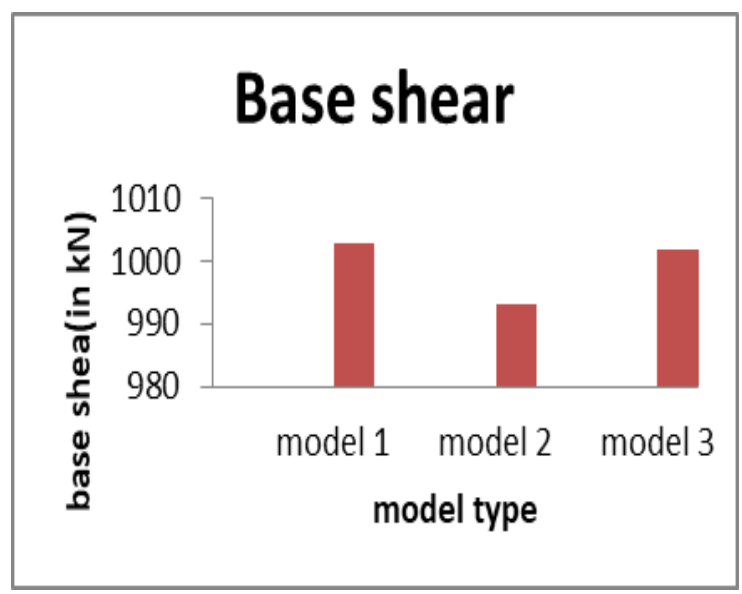

Fig 8a -Base shear comparison

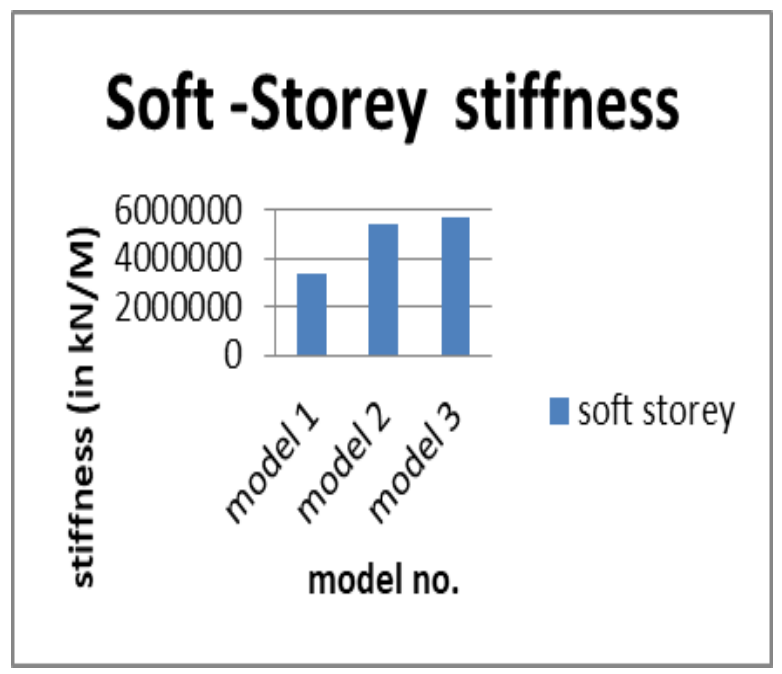

Fig $8 b$-storey stiffness of ground soft storey comparison

\section{Storey drift due to RS}

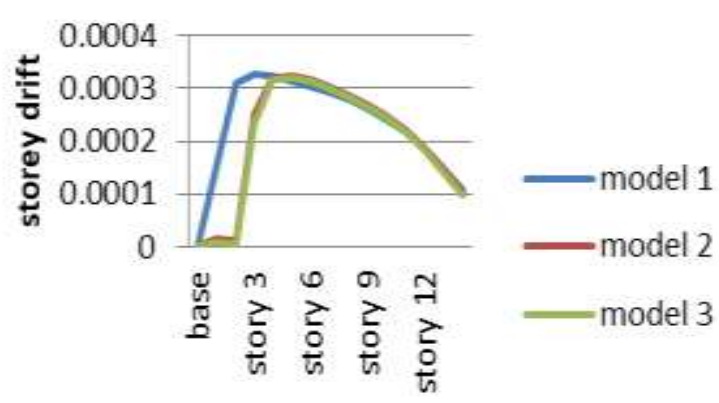

storey no.

Fig 8c- Storey- drift comparison

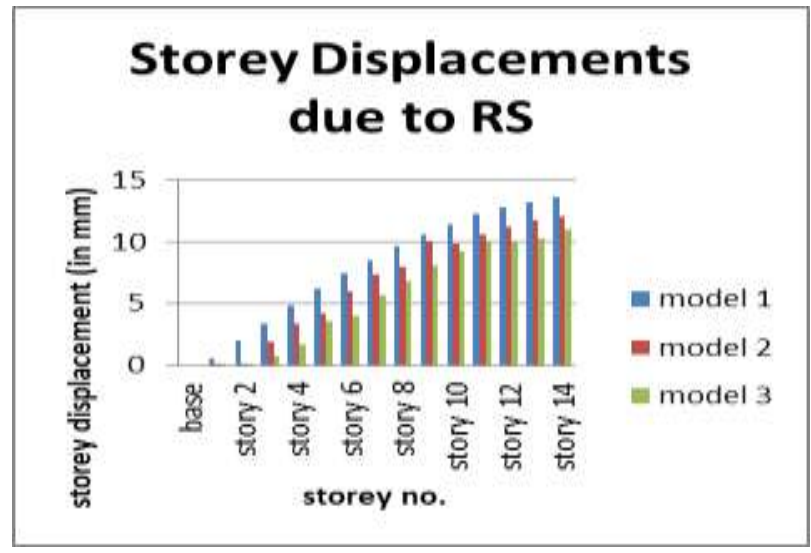

Fig 8d -Storey-drift comparison

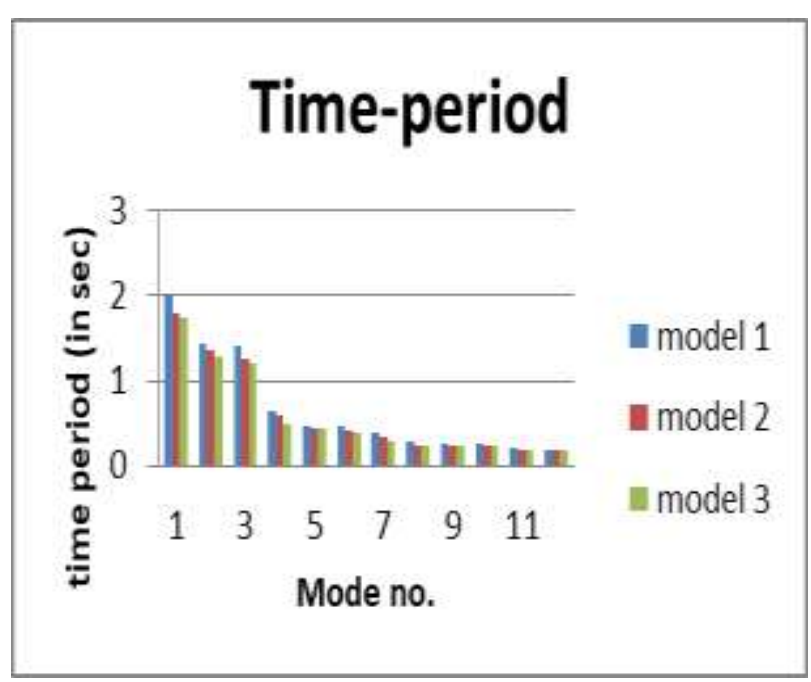

Fig 8e- Time-period comparison 


\section{International Journal of Engineering Applied Sciences and Technology, 2019 Vol. 4, Issue 3, ISSN No. 2455-2143, Pages 226-229 \\ Published Online July 2019 in IJEAST (http://www.ijeast.com)}

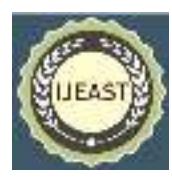

\section{CONCLUSION}

This paper presents an innovative approach for the seismic design of structures by use of crescent shaped bracing and its various configurations in ground soft storey from we conclude that there is about :

1) 12 to $14 \%$ reduction observed in storey displacements.

2) Storey drift have also reduced by $20 \%$. Base shear have also decreased by small amount.

3) Addition of bracing in ground soft storey have increased the stiffness by almost $60-68 \%$.

4) Fundamental time period decreases when provision of different types of Crescent shaped bracing are considered in soft storey to about $11-12 \%$ as compared to bare model.

5) Also it is found that model type 2 CSB System proves to be effective from economical point of view.

6)Base shear have also increased by small amount due to addition of bracing.

\section{ACKNOWLEDGEMENT}

It's a great pleasure and moment of immense satisfaction for me to express my profound gratitude to my guide Prof. Prof. Roshni John, Head of Department whose constant encouragement enabled me to work enthusiastically. Her perpetual motivation, patience and excellent expertise in discussion during progress of the project work have benefited me to an extent, which is beyond expression.

Mr. Pratish Shrikhande (Structural Engineer) ,Louis Berger $\mathrm{G}$ for guidance, but these are the only means at my disposal, I put on the record sentiments of deepest gratitude for them invaluable suggestion and guidance from time to time

\section{REFERENCE}

[1] Trombetti, T., Silvestri, S., Gasparini, G. and Ricci. , I. (2009), Stiffness-Strength-Ductility Design Approaches for Crescent-Shaped Braces, The Open Construction and Building Technology Journal 3, 127-140.

[2] Devi S. A. and Nandini G., "Seismic Demand Study Of Soft Storey Building and its strengthening for seismic resistance ," Int. J. Emerg. Trends Technol.Comput Sci, Vol 5,No.2,2016.

[3] Palermo M., Silvestri S., Gasparini G.,. "Crescent shaped braces for the seismic design of building structures," Materials and Structures, vol. 48, pp. 1485-1502, 2014.
F. Gonzalez and J. Hernandez, " A tutorial on Digital Watermarking ", In IEEE annual Carnahan conference on security technology, Spain, 1999.

[4] Chan RWK R. and Zhao ,Daoud "Mitigation of Seismic Risks to Soft -Storey Structures Using Toggle-Brace Damper Systems", Applied Mechanics and Material, August 2013.238, 833-837, 2012

[5] Roziana I,Khalid 1,Izzul Syazawan I. “ Retrofitting of soft-storey building by using different type of bracing system", IOP conference series: Material Science and Engineering, Vol.431, 2018, pp.173 - 177.

[6] IS 1893 (Part I): 2016, 6th Edition, , Criteria for Earthquake Resistant Design of Structures; Bureau of Indian Standards, New Delhi, India

[7] IS 13920: 2016, Ductile Detailing of Detailing of Reinforced Concrete Structures Subjected to Seismic Forces Bureau of Indian Standards, , New Delhi, India

[8] Dia Eddin N.,Ali Khalid K., Abbas Jaraj Mohammad," Comparative response assessment of steel frames with different bracing system under seismic effect

[9] Mohamed R.,Raneesh K.,'Effect of soft-storey on tall buildings at different levels.

[10] Carlo Ruiz C,Ingenerio Civil,'Seiemic Design of softstorey buildings. 